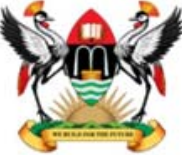

East African School of

Higher Education Studies \& Development
Makerere Journal of Higher Education

ISSN: $1816-6822 ; 9$ (1) (2017) $133-160$

DOI: http://dx.doi.org/10.4314/majohe.v9i1.11

(C) The Author(s) 2017

Reprints \& permission: EASHESD

http://ajol.info/majohe

\title{
Student Politics at Makerere University in the Lens of Schmitter and Streeck’s Framework: Student Leaders and Political Parties
}

\author{
Taabo Mugume ${ }^{1, *}$, Thierry Luescher ${ }^{1}$ \\ ${ }^{1}$ University of the Free State, South Africa; ${ }^{2}$ Human Sciences Research Council/ University of \\ the Free State, South Africa [*Corresponding author: mugumetj@ufs.ac.za]
}

\begin{abstract}
While the influence of political parties on student politics has been a topic of investigation for a long time, little research has been done in relation to Africa's young democracies and the re-emergence of multi-party politics in these countries. It is with this understanding that this study assesses a theoretical framework adapted from Schmitter and Streeck (1999) to explain the nature of the relationship between student politics and political parties in Uganda. The paper highlights need for changes to the Schmitter and Streeck framework to ensure better analysis of the relationship. The study finds that the recruitment of student cadres seems the most important function of party-political involvement in student politics, while student leaders gain goods and services as part of the benefits of their association with political parties. Additionally, while student leaders are influential in the weaker parties, there is still an element of party control over the leaders, particularly when student leaders expect to pursue a political career upon graduation. Finally, reflecting on the analysis, conceptual changes are proposed to the framework for a more critical analysis of student politics.
\end{abstract}

Keywords: Student politics; Democratisation; Activism.

\section{$1 \quad$ Introduction}

Student interest representation in higher education has historically been informal, and mostly by means of protests and direct access to university leaders; the formalisation has meant institutionalising such student participation mainly in existing structures of university governance as one of the latest popular reforms internationally to student politics in institutions of higher 
learning (Munene, 2003). Numerous progressive scholars have advocated for the inclusion of student leaders in institutional decision-making, while outlining various reasons for such inclusion (Luescher-Mamashela, 2013; Olsen, 2007). The international trend in the promotion of democratic governance, in addition to a more recent shift in institutional management to managerialism in the late 1990s and 2000s has in many ways been instrumental for the inclusion of students in some aspects of university governance, such as quality assurance (Luescher-Mamashela, 2010; Luescher-Mamashela \& Mugume, 2014; Nkata, 2004: 9).

Data for this paper was generated through in-depth interviews with three types of main actors involved in the relationship between student leaders and political parties at Makerere University (MAK). They include: four student leaders who were elected members of the guild cabinet of the 2013-2014 academic year; the dean of students of the institution; eight party leaders (two per party), who were mainly responsible for working with the youth from the Democratic Party (DP), Forum for Democratic Change (FDC), National Resistance Movement (NRM) and Uganda Peoples' Congress (UPC). The data was categorised into main themes and concepts by means of a process of broad brush and fine brush coding, which was informed by a theoretical framework (Babbie \& Mouton, 2001; Neuman, 1997: 421).

The presentation of data and discussion begins with a brief insight into the relationship between multi-party politics and student leadership. The second section introduces Schmitter and Streeck's (1999) theoretical framework along with various studies which have previously adopted and used the framework for the purpose of studying student organising, i.e. the study of the German student union "freier Zusammenschluss von StudentInnenschaften" (fzs), and two studies of student representation in Europe and student representation in African higher education. The process of adapting the framework to the case study of Makerere University is discussed before outlining the four main adapted associative actions proposed by the framework, which are then applied to this case of student politics and multiparty politics in higher education.

\subsection{Student Politics and Multi-Party Politics}

One of the main reasons given for the historical influence student leaders have held in national politics within the former colonies such as in most African countries, has been that;

There are fewer competing political forces and this permits students to play a more direct and powerful role. The mass media are weaker, parliamentary systems are often ineffective or non-existent, trade unions, consumer groups and the myriad of interest groups typically found in the Western industrial 
nations are missing, and the educated middle class is small (Altbach, 1984: 637).

Given the changes in the national political systems of most African countries through mainly adopting democratic political leadership (Gyampo, 2013), the advantages of democratic rule such as political stability have also had an effect on the higher education systems. Various scholars have shown the increase in enrolment rates on the continent arguing that the continent is experiencing massification at institutional and national levels (Mohamedbhai, 2014; Luescher, 2016). Hence with such changes gaps arise in the literature, calling for a need to assess, for example, the effect of student activism, to try and find out the reasons for changes in activism if there are and the contemporary forms of activism. Given the historical argument that "the reaction of the political system to student activist movements helps to shape their actions, orientations and, of course, the impact they have on society" (Altbach, 1984: 638). Weinberg and Walker (1969: 82) have argued that, the recruitment of young leaders and student leaders' ambitions for political careers are at the centre of the relationship between student leaders and political parties.

While Altbach (1968) noted the failure by parties in Europe to replace old leaders as a problem that led to the revolts of 1964 since most student activists felt that party leaders were old men who did not understand the challenges students at the time were facing. As early as the 1980s Altbach argued:

Authorities have occasionally tried to co-opt student movements and organizations in order to obtain their cooperation and to ensure campus calm. Student leaders have been brought into the government and authorities have listened to student grievances. Such tactics sometimes work to defuse dissent and also to bring different perspectives to the political debate (Altbach, 1984: 652-653).

Hence in a democratic regime, student participation in political party spaces becomes important in influencing student activism for example considering Lipset's (1966) argument that universities in general are training grounds for future elites and this is more-clear in underdeveloped countries around the world. It is also noted that even during their time as students they also play an important role in the political life of the country through their movements and activism. Therefore even in the presence of oppositional party politics for example in Africa, student activism remains relevant. In relation to party politics it is argued that;

The core of student leadership tends to be politically aware and often ideologically oriented. Student leaders are more likely than their less active compeers to be members of political organisations prior to their involvement in activism. Activist leadership is often politically involved during periods 
of campus quiet; in many instances, student political leaders are a part of an existing political community (Altbach, 1989: 102-103).

Accordingly, Altbach (1984) highlights that external actors (e.g., political parties) may try to manipulate the political situation using student politics or student leaders for the external actors' gain. Luescher-Mamashela and Mugume (2014) posit on the evidence showing the presence of the relationship between student leaders and political parties in various countries on the African continent. They argue that the relationship appears to be based on resource exchange between the two actors with both student leaders and political parties gaining from the relationship in various ways (also see Mugume 2015). Thus, they highlight the interest-based reasons for the two types of actors to enter into and maintain a relationship. To interrogate the related reasons and processes, the Schmitter and Streeck (1999) framework is employed below, considering how it has been applied before, and how it can be adopted to a study of the relationship between student leaders and political parties at MAK.

\section{The Schmitter and Streek Theoretical Framework}

\subsection{The Organisation of Business Interests: Studying the Associative Actions of Business in Advanced Industrial Societies}

The Schmitter and Streek (1999) framework was initially designed in an attempt to study the reasons why independent business investors (i.e. capitalists) in industrialised countries come together to protect and represent their interests through organisations. The framework criticises the attention given to workers by most scholars for organising themselves while there is noticeable silence about capitalists organising themselves. Two reasons are presented for such lack of attention. Firstly, they argue that it is as if scholars question the legality of capital owners organising themselves through organisations to protect their interests, while on the other hand employees coming together to form unions in order to protect their interest is looked at as brave or courageous. Secondly, since business owners conduct business in private and with concealment, accessing information to write about Business Interest Associations (BIAs) may become a hindrance to scholars (Schmitter and Streek 1999: 9).

Therefore given the challenges, the framework attempts to address the subject of organising capitalists and the complexities involved in such relationships. Moreover, Schmitter and Streek (1999: 12) argue that independent capitalists ought to compete rather than cooperate with each other 
and that business culture tends to lack trust between investors. Hence they argue that to understand this relationship, at least one should consider why the capitalists would want to come together given their differences, what the required organisational mechanisms are for these investors to work together in organisations that protect them to achieve their business objectives. Furthermore the question arises whether organisations formed to protect the interests of investors end up assuming control over their members in the same way organisations formed by employees, i.e., trade unions, assume control over their members (Schmitter and Streeck, 1999: 10). The framework considers two potential 'logics' used in organising the above interests: a logic of membership and a logic of influence. However in relation to these two competing logics, it is argued that BIA should organise themselves in two ways. Firstly, they should structure their associations to act so as to offer sufficient incentives to their members to extract from them adequate resources to ensure their survival, if not growth. Secondly, they must be organised in such a way as to offer sufficient incentives to enable them to gain access to and exercise adequate influence over public authorities (or conflicting class associations). They have to therefore extract from this exchange adequate resources (recognition, toleration, concessions and subsidies) which enable them to survive and prosper (Schmitter and Streeck, 1999: 19).

The framework focuses on two main logics of exchange in order to explain the different levels of interaction which leads to the exchanges. It expresses how capitalists interact with the organisation and then how such an organisation which is meant to represent their interests interacts with the state, state institutions, as well as workers' organisations such as trade unions.

\subsection{The Logic of Influence and Membership}

The logic of influence relates to how organised interests influence policy processes and how such influence can be directed, directly at the state, or at other state institutions or to actors such as the trade unions in the case of the workers' relation to BIAs. The framework outlines that in the process attention is given to factors such as the rules of the game, access, the institutional frame work, political culture and many others. The framework focuses on detailed explanations of factors or variables which influence the relationships. Specific circumstances can then explain the national and sector specific conditions of the relationship (Schmitter and Streeck, 1999: 19-39).

The logic of membership is meant to outline a number of factors which can affect members of the business community. It relates to how members get involved in the formulation of goals they design to protect their interests. These goals are then promoted by the BIA on behalf of its members. The framework offers the following variables: membership numbers, equality, competition, 
interdependence, heterogeneity, turnover, social cohesion, profitability and growth (Schmitter and Streeck, 1999: 19-24). Figure 1 below shows this relationship in the two outlined logics, i.e., membership and influence, and how the different actors theoretically interact.

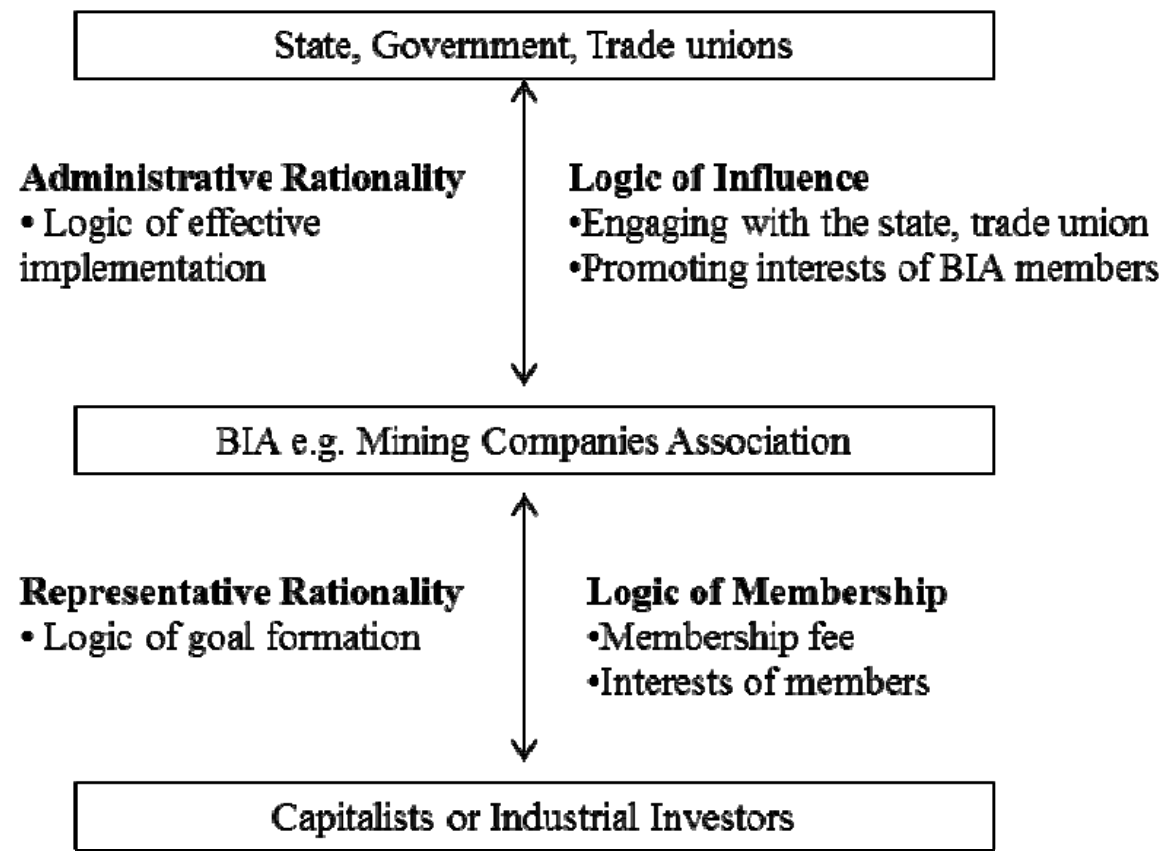

Figure 1. Relationship among capitalists, BIA and the state, state agencies, trade unions.

Figure 1 illustrates how the different actors associate considering the two logics of association. The Figure indicates that capitalists or investors may form a BIA which can protect their interests as members. The BIA therefore ensures that the interests of its members are promoted and defended before other actors, and that is referred to as the logic of membership. Thus, the interests or agendas of members are set and then advocated by the BIA. The BIA intentionally influences, for example, policy positions in favour of its members and that is referred to as the logic of influence above. Through a representative rationality, goals are formulated by the members of a BIA which are then defended by the BIA and this is referred to as the logic of goal formation, while the different sufficient ways used to ensure proper implementation and thus to achieve the set goals are referred to as the logic of effective implementation.

Schmitter and Streek argue that "attending to all of these would involve an association in four types of activity: Participation for Members, Representation of Members, Services to Members and Control over Members - each with a 
corresponding type of modal 'good"' (1999: 20). Thus, the framework outlines four types of associative actions and related types of goods in a matrix. The goods may be solidaristic, public, monopolistic, selective or authoritarian in nature. It is argued here that "as associations structure themselves organisationally to provide only ... one "logic" of social action, they transform themselves, at the extreme, into another type of social organisation (Schmitter and Streeck, 1999: 20). Such organisations in relation to the modal "good" include a club, movement, government and a firm respectively. Figure 2 shows the above explained relationship in more detail. 
Mugume \& Luescher: Student Politics at Makerere University

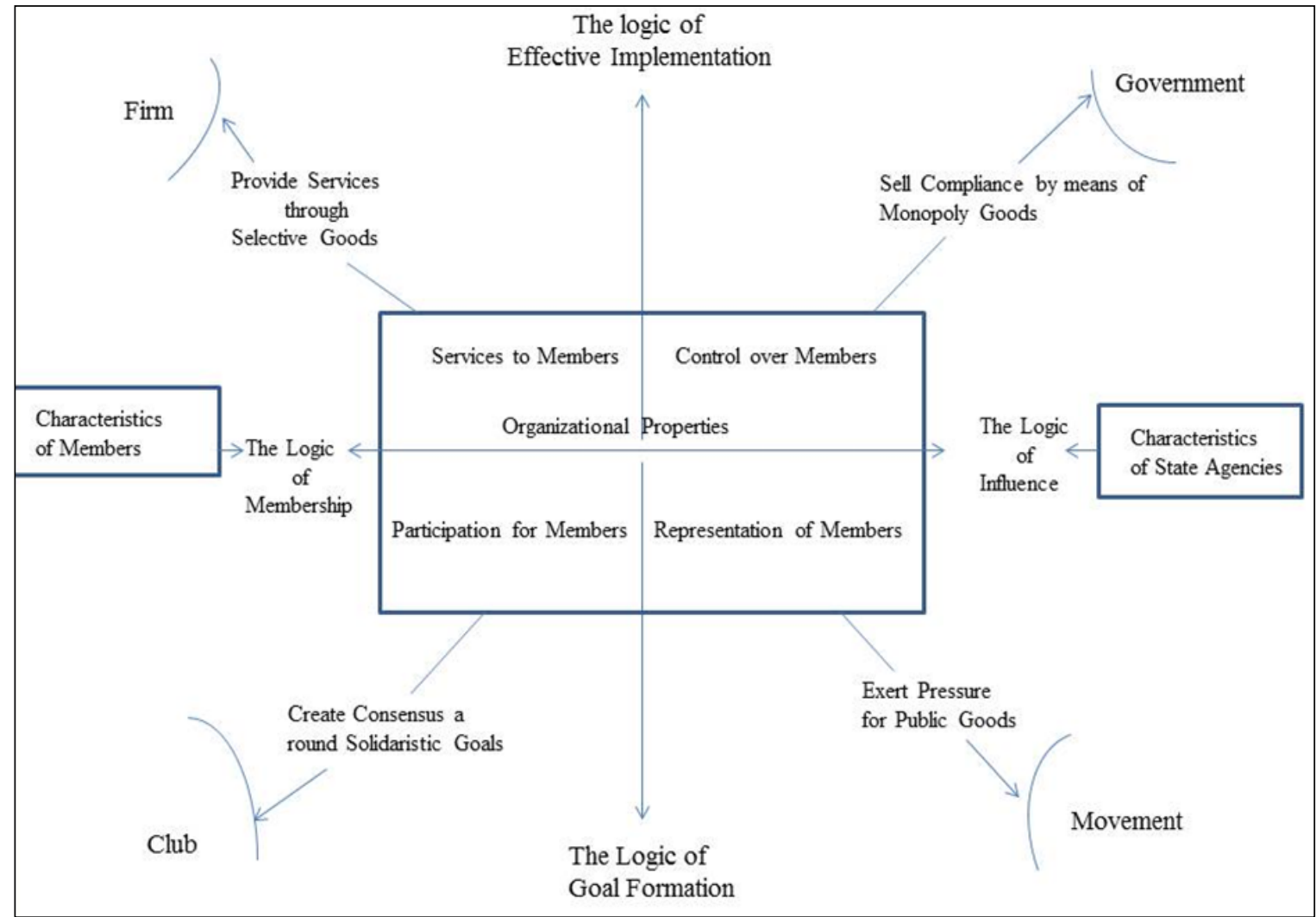

Figure 2: The competing logics of associative action affecting organisational properties Source: Schmitter and Streeck (1999: 21). 
Figure 2 illustrates a theoretical relationship between the two sets of logical alternatives. Attending to all of these would involve an association in four types of activities and four corresponding goods at the extreme, as named above.

The framework has been used before by other scholars to study student representation, particularly in higher education in Europe and more recently in Africa as discussed below.

\subsection{The Study of the German Student Union (FZS)}

Jungblut and Weber (2012: 47) used the Schmitter and Streeck (1999) framework to study the development of the German student union, "Freier Zusammenschluss von StudentInnenschaften" (FZS) from the time of its formation in 1993 to 2010. Since FZS was the main national students' union, they considered the logic of membership in their study by assessing the multilevel memberships for student union organisations at the local level and union membership within an academic institution, and the organisational structures of unions (at local level or institutional level). Therefore as individual students became members of unions at the local level, unions joined FZS which is a collective of interests of local unions at the national level (Jungblut and Weber, 2012: 49-50). The two competing logics of membership and influence are highlighted through FZS members paying a membership fee which then keeps the organisation going (logic of membership). Then FZS represents their interests as members through interactions with the state and other public authorities/institutions (in-terms of a logic of influence). They explain two main areas of development for FZS in relation to the two logics: ideology and membership development-logic of membership, and communication and internal organisation-logic of influence.

\subsection{The Study of Student Representation in Europe}

Klemenčič $(2012: 2,7)$ introduces the special issue in the European Journal of Higher Education using the Schmitter and Streeck (1999) BIAs framework to compare how students are represented by various student organisations in Western Europe. She explains that the formation and structure of organisations representing interests vary depending on the interests of members and also how the organisation interacts with the state and other political actors, and public authorities. Klemenčič explains that through the logic of membership, students in Europe are represented by National Students Associations. As members, students contribute to the determination of the organisation's structure, resources, political agenda, mode of action and output (Klemenčič, 2012: 7). In terms of the logic of influence, these student associations take with them the decisions made by their members and engage with state institutions (national 
and continental actors in their respective countries). She also uses the framework to show the systems of student interest representation and intermediation in Europe. However Klemenčič does not comprehensively refer to the matrix by Schmitter and Streeck (1999), most especially in relation to the logic of goal formation and the logic of effective implementation even though they are implicit in the organisational properties of these student organisations.

\subsection{Study of Student Representation in Higher Education in Africa}

Finally Luescher-Mamashela and Mugume (2014: 511-512) use empirical data from nine African countries to explain how student representation has evolved by means of a shift from non-institutionalised to institutionalised student politics as a current trend. In an attempt to understand the new relationship between political parties and student politics on the continent and how that relationship impacts on the representation of students, they apply the Schmitter and Streeck framework (1999). They argue that there is a high level of resource exchange, both material and non-material, between student leaders and political parties in the relationship. They propose that this mutual resource exchange influences the student leaders' level of autonomy of representing the interests of students and they argue regarding the different levels of resources exchange that, "they produce four types of associative actions which respectively may be called, participation of student leaders, services to student leaders, representation of student leaders, and control over student leaders" (LuescherMamashela and Mugume, 2014: 511). Participation of student leaders refers to student leaders being part of the political party's structures and activities, and in the process advancing students' interests. Services to student leaders may refer to the exchange of material and non-material resources. Representation of student leaders refers to the political party taking on the role of representing student interests, and Control over student leaders refers to the loss of autonomy by student leaders in the process of exchanging resources (LuescherMamashela and Mugume, 2014: 511). These four associative actions suggested will be discussed in more detail in the process of adapting the Schmitter and Streeck (1999) framework.

\section{Adapting the BIA Framework to the case of Makerere University and Possible Changes}

The Schmitter and Streeck (1999) framework focuses on the structure of BIAs or organisations as the dependent variable. Therefore much of how BIAs relate to the capitalists individually or as firms and how they relate to the State is reliant on how they are structured or organised. Conversely, the main question 
for this study is directed at attempting to understand how through the lens of this framework, the relationship plays out? In other words how it impacts on student leaders and their constituency and the political parties involved? In correspondence with the original framework, Byaruhanga (2006) indicates that resources play an important role in the interaction and motivation for establishing and maintaining a relationship between student leaders and political parties.

In keeping with the above discussion mainly in relation to membership, the naming of the logics will change from "logic of influence" and "logic of membership" to "logic of influence" and "logic of membership and interests" respectively so as to focus on aggregated interests, rather than a complete focus on membership since all registered students automatically qualify as members whose interests are represented by student leaders at a first level. Also, while in the original matrix the associative relationship takes place among the three main actors (capitalists, BIA, State-state agencies), in the adapted framework the associative relationship takes place among student leaders (representing students), political parties (as interest association) and the state (state agencies) or university administration. Figure 3 outlines the theoretical associative relationship among the three main actors in the new framework.

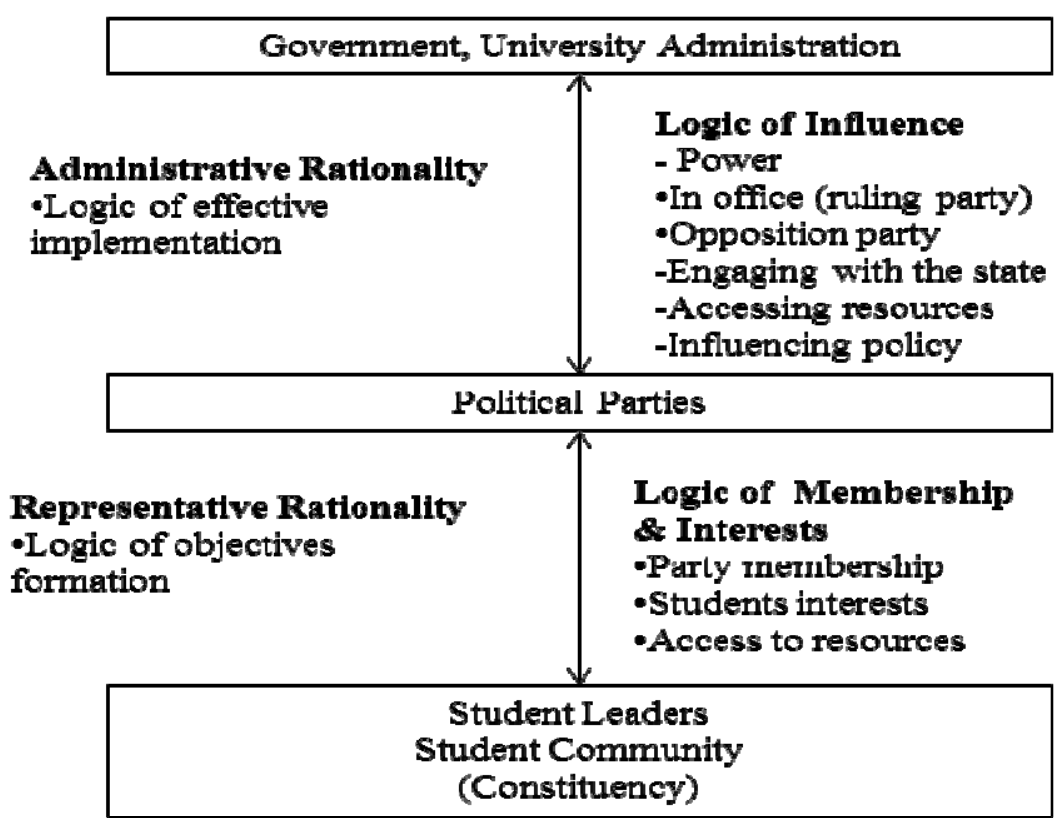

Figure 3.The associative relationship among student leaders, political parties and the state. 
Figure 3 illustrates the competing logics of associative actions affecting aggregated interests of student leaders (SL) and political parties (PP). It shows how the different actors associate considering the two logics. Student leaders do advocate for interests of students who are members of a constituency, they promote and defend them before the political party. While the party also influences state and university authorities to access the much needed resources, resources which are always needed by student leaders such as campaign funding, leadership training workshops and many more costly activities are considered. The outcome of this defence of student interests, is influenced by whether the political party is in power or not.

The relationship mapped above will result in an associative activity of four types as noted above by Luescher-Mamashela and Mugume (2014: 511): participation of student leaders; goods and services exchange; representation of student leaders; and control over student leaders by the political party. Each associative action impacts differently on student leaders' level of autonomy. In relation to the Schmitter and Streeck (1999) framework, this action theoretically involves a transformation at the extreme in which one of the two actors, i.e., either student leaders or the political party, gains some level of control over the other actor, or loses power to the other actor. Therefore understanding the circumstances under which student leaders may have more, or less autonomy within a political party, becomes important to understand when they may be able to influence party decisions or alternatively, when they may not. Figure 4 below shows the revised matrix for this study. 
Makerere Journal of Higher Education

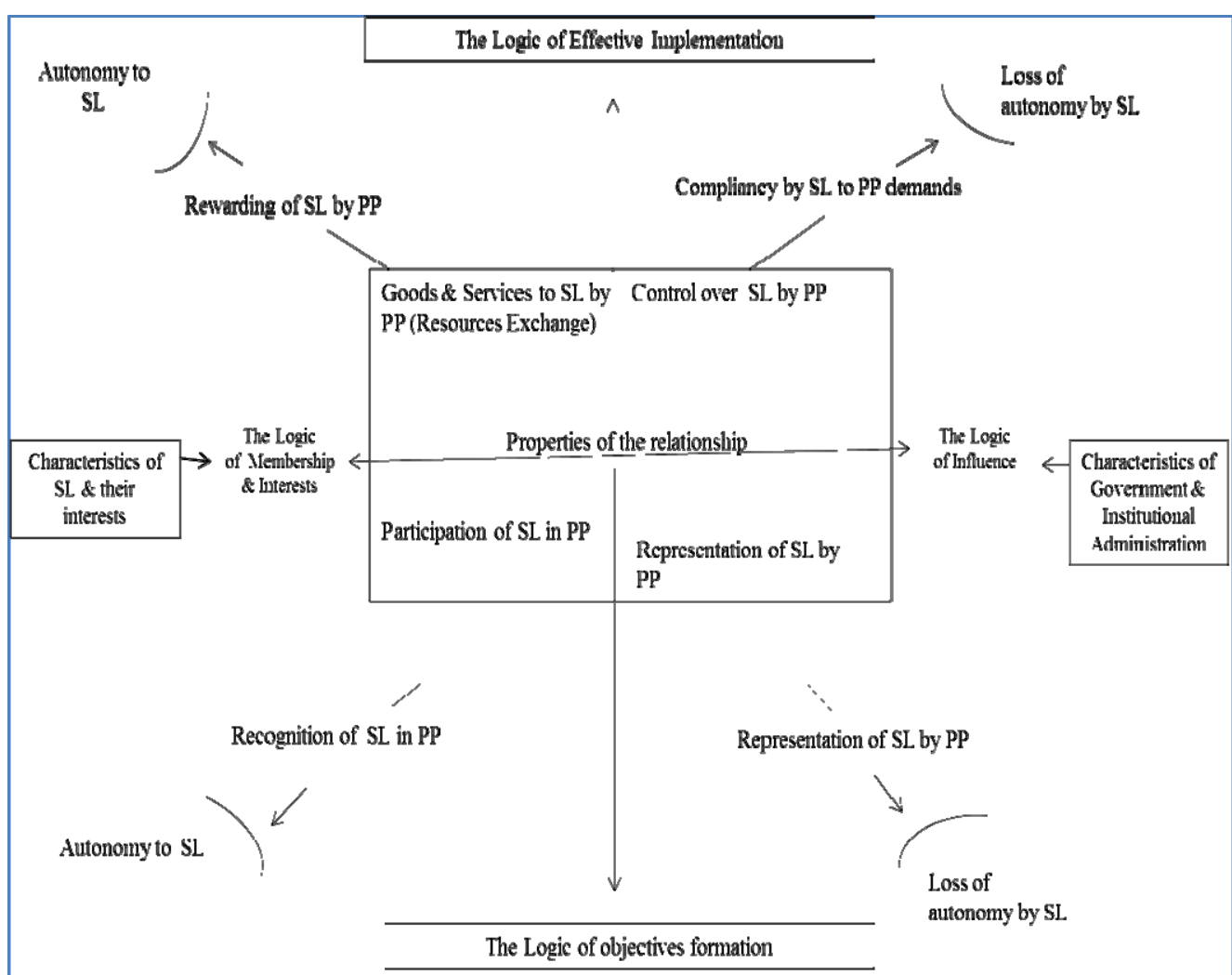

Figure 4. The competing logics of associative action affecting the relationship between student leaders (SL) and political parties (PP) Source: Adapted from Schmitter and Streeck (1999). 
Figure 4 illustrates the relationship as argued through the framework, highlighting the four associative actions as named earlier with each representing a different way of associating between a political party and student leaders, even though the activities outlined in the matrix above are not mutually exclusive.

The framework suggests that autonomy is influenced by resources and incentives in two ways. One way is that for example the more incentives a political party avails to student leaders, the more control it will have over them (other factors considered constant). While the more resources a political party may perceive to be receiving from student leaders, the more autonomy student leaders will be able to enjoy even within the political party. However, it is important to note that a political party accesses more resources if it runs the government (as a ruling party) in comparison to the opposition (Byaruhanga, 2006). Therefore as noted, the amount of resources a political party can access and distribute affects its influence or control over student leaders. The associative actions outlined above in the four types of activities are discussed in detail below along with empirically identifiable indicators.

\subsection{Participation of Student Leaders in the Political Party}

Participation of student leaders in the political party as a type of associative action refers to the space afforded to student leaders within the political party in order to be part of the decision making process of the party. Through being part of the party's decision making structures or committees such as National Executive Committee (NEC) or delegates conferences, student leaders can promote the interests of their constituency i.e., the student community. Student leaders can then be part of the different activities in the party such as voting on party policy decisions thus retaining more power and more autonomy.

\subsection{Representation of Student Leaders}

This refers to the representation that the political party affords student leaders. The political party represents students' interests on behalf of student leaders rather than student leaders representing students' interests themselves. Thus student leaders raise their issues in the party and then the party leadership decides on such issues before taking a public stand. This does not mean that student leaders cannot be part of such representation, but whether student leaders are part of the team in the party to represent their interests through the political party is a decision made by the party together with the student leaders. Therefore the 'representative' in this instance is the political party leadership on behalf of student leaders and by extension the students they represent. This 
associative action thus involves directing more power to the political party and less autonomy for student leaders.

\subsection{Goods and Services Exchange}

This refers to exchange of the different goods and services which may be directly or indirectly afforded to student leaders through the political party. Student leaders organise the interests they plan to achieve in the process of associating with political parties. The services provided by the party in the process may include the training of student leaders (e.g., through party workshops and seminars); helping student leaders with campaign advice; for example on how to hold a successful protest. This kind of associative action leads to empowering student leaders and gaining potentially more autonomy. However, as political parties give student leaders incentives, they also have expectations and these may include material or non-material resources in a relationship of mutual exchange such as student leaders recruiting new members for the party; student leaders promoting the party's agenda in public; and student leaders representing the party when called upon.

\subsection{Control over Student Leaders}

This refers to circumstances whereby student leaders make their decisions following party orders. This therefore refers to student leaders exchanging their power for goods and services the political party may be willing to offer. Student leaders become captive to political party decisions and in the process accept being controlled by the political party. This associative action therefore results in loss of power for student leaders and less autonomy.

The adapted framework will be applied to illustrate its ability to increase our understanding of the relationship between student leaders in Makerere University and political parties in Uganda.

\section{Applying the Schmitter and Streeck Framework to Makerere University}

\subsection{Participation of Student Leaders in Political Parties}

\section{1.1 Participation of student leaders in party structures on-campus}

In our interview, the dean of students confirmed the presence of party structures on campus and he further offered more insight into how the administration views the influence of political parties on student politics at the institution. 
Officially, management and council discourage direct involvement of external forces in determining the student leadership. But the university does not prevent students becoming members of associations even if they are political [such as] political parties. That is the official position. But over the years in practice the external actors have come in and as we speak now the elections of guild leadership or student leadership at all levels are heavily influenced by political parties. To the extent that now they select candidates, they sponsor candidates and so on. [The] main influence on student leadership here is by political parties and cultural groups (Interview with dean of students, October 23, 2013).

While institutional management allows party influence on campus but critically monitor the relationship and have preferred not to allow such influence. Consequently, despite the concerns, management respects the right of students to affiliate with political organisations. Clearly, political parties are highly influential at the institution.

The party leaders interviewed (October 17, $2013 \&$ \& 22, 2013), argued that even though political parties have chapters at MAK most of them are not very active. They noted that the recruitment of students into political parties increases during student election campaigns. Therefore the campaign period is utilised to identify and recruit new members. The MAK-based political party chapters are recognised by the mainstream parties under their respective youth wings. Most student leaders interviewed (October 22, 2013 \& 23, 2013), explained that students who are not in leadership don't really understand the details or the complexity of the relationship.

Clearly there is active engagement between student leaders and party leaders through the party structures on campus as noted in the discussion above. However to consider whether this level of engagement highly contributes to the level of autonomy student leaders may enjoy or rather constrain them, it is important to consider what happens off-campus.

\subsubsection{Participation of student leaders in party structures off-campus}

Interviews with guild leaders (October 23, 2013) show guild leaders use their structures on campus to connect with the off-campus structures of their respective party, more specifically the youth wing of the party. The participation in the structures off-campus happens in different ways as noted below.

This may afford student leaders the opportunity to represent student interests in forums beyond the university. UPC and UYD leaders indicated that affiliated student leaders were invited to their respective national delegates' conference. For instance, a UYD party leader reported that each university chapter of UYD in the country sends three representatives to the party's national delegates' 
conference (Interview with UPC leader B, October 17, 2013; UYD leader, April 15, 2014). It is clear that this form of participation provides the opportunity for student leaders to voice students' concerns at the national level; it therefore provides an opportunity of empowering them within the party structures. They may consequently enjoy a level of influence to air out certain concerns as delegates, but that may not necessarily mean they are independent or have autonomy from the party as referred to in the theoretical framework. They may have a level of authority to influence, but within the party structural confines. This may mean having more power to influence, but they may lack the independence mainly to make or influence the final decisions. Hence in relation to the context of participation being discussed, empowerment appears to be the more appropriate concept to use since they may be empowered to influence the process, but not the final decision made about a particular issue.

The empowerment of student leaders inherent in forms of participation may be expressed in different ways. According to a UPC party leader, it is mostly through influencing change.

During the last national election campaigns the managers [of the building] were not allowing posters here [at the party head office]. The youth came and forced that to happen and it happened. They sat here [in protest] until the manager said we are allowing [it] but please don't put [posters] everywhere. We made big posters and stuck them on walls in the building. When there was a leadership problem [within the party] again the youth came and took over the party headquarters. They came in the morning, overpowered one of our security guards and entered the offices, and locked themselves in until the issues they raised were heard. We had a meeting and resolved the leadership grievances they had (Interview with UPC leader A, October 17, 2013).

The party leadership did not punish the youths from MAK for these actions. This highlights how student leaders can participate within a political party in different ways, for example using student activism, sit-in etc. Moreover, it indicates that they are able to exert considerable power within political party structures. This further highlights not autonomy but influence they may enjoy within party structures. As noted above, it is the party leaders who in the end resolve the problems raised; students could only exert influence and pressure. Therefore student leaders do not enjoy autonomous power but enjoy influence within party structures. Student leaders who also have leadership roles in party institutional structures, may enjoy a level of authority within the party and thus may be listened to, they may even participate in decision making structures, but they do not independently determine the final decisions made.

In relation to the established theoretical framework, it may be argued that participation of student leaders in political parties avails them additional 
platforms to raise student concerns and therefore increases their power and influence overall. Similarly, some student leaders claimed to be viewed as national leaders:

Even though I am a student leader, I am viewed in my own respect as a national leader because students' issues are not issues that are limited to a specific age group or ethnicity. Students are from all over the country, different nationalities, they are from different age groups; so at the end of the day being a leader of that kind of constituency puts me out as a national leader (Interview with guild leader A, October 23, 2013).

Other guild leaders explained that it is the guild president in particular who is most recognised by the political parties and who therefore could claim to be a national leader (Interviews with guild leaders B and D, October 23, 2013 \& 24, 2013).This shows he influence and the power student leaders may enjoy as upcoming party leaders. Since the "great prize" is the guild presidency, political parties seek to influence the process of choosing the candidate who represents the party; in turn, the guild president becomes a national leader in her/his party. Thus, another party leader argued that:

They [student leaders] are taken as serious leaders. That is why when there are campaigns in MAK all political parties go there to see who is strong so that they can convince them to join their party. So political parties go there to mobilize for support and recruit possible candidates to become their members. MAK is looked at more seriously in comparison to other universities in the country (Interview with NRM leader A, October 22, 2013).

MAK does have a special status in this respect, as it represents a microcosm of Ugandan society. In this regard a student leader argued that "there is a perfect correlation between leaders who move from MAK and go to the national scene" (Interview with guild leader A, October 23, 2013). In addition, student leadership at MAK is often a precursor to a career in the party and in national politics hence many prominent national leaders were guild leader.

Thus, the interviews vividly confirm Byaruhanga's (2006: 145) earlier findings that the relationship between student leaders at MAK and political parties in general is historical and has created a succession "political culture or tradition" over time. Hence, student leaders in other universities that ban political party activities on campus (such as the Uganda Christian University) rarely make the transition into national politics in Uganda (Mugume and Katusiime, 2016).

The discussion above shows that student leaders actually don't enjoy autonomy within the party but rather they get empowered at different levels depending on the context. Considering Figure 4, student leaders-need a level of 
autonomy within the party, which as noted above, they actually may not enjoy to authentically represent their constituency. Evidence shows that student leaders participate in the decision making processes of their respective parties hence they may be able to represent the student constituency. Furthermore, it may be hard to argue that student leaders participate in the relationship with a political party only to represent their personal interests since their own interests may overlap with the interests of the general student population given that they are also students.

\subsection{Representation by the Political Party}

According to guild leaders A and B (interviewed, October 23, 2013) opposition parties may not be able to influence the university, for example, if students complained about a policy, since MAK is a public university the ruling party has more influence on policy. Therefore an opposition party can only influence such policies through parliament, and for an issue to reach parliament it should be advocated for within the party to appear on the party agenda in the House. Since some of these parties explicitly allow student leaders into their structures, this creates room for student leaders to advocate for students' interests in the party. Hence students' concerns may end up on the floor of national parliament and get defended by the party of the respective student leaders raising such a concern. Therefore, political parties do represent student leaders' concerns, but there are limitations: whether it is a ruling party or opposition; whether student leader/s are able to argue for a specific student concern to appear on the party agenda. Conversely, student leaders are a small constituency within a political party and therefore have less influence on party policies. If one of the other bigger constituencies within a party were to go against a policy it may not gain a majority and most likely not be implemented by the party. Political parties mostly intervene if issues raised gather national attention:

Political parties cannot solve problems which are here [at the institution] but if you put it in parliament, you're most likely to get their voice. You have to just struggle and make sure you push the issue to their level where they can come in at a more national level. The time when we took the university to court, our members of parliament who are lawyers helped us and gave us affordable legal services but also because it was about student fees, it touched the whole nation (Interview with guild leader B, October 23, 2013).

This highlights the limitations of political parties in the process of representing student leaders' interests and this allows student leaders to consider other means of getting their issues heard, most especially if such issues cannot easily get national public attention. 
When the party is in power in the case of a public university, it is able to influence policy indirectly, thus it would be able to represent student leaders' concerns in the process. Student leaders would have less autonomy in the process, while an opposition party which struggles to represent students' interests would leave student leaders more empowered since they would have to try and resolve their concern until they are of national concern. At the institutional level student leaders appear to be constantly trying to negotiate their way to solving problems with management, mostly informally rather than through the official structures. How are the resources exchanged?

\subsection{Transactions between Student Leaders and Political Parties}

Student leaders generally get help from their respective political parties during campaigns, after the campaigns and even after graduating. However, in this resource exchange relationship political parties also have expectations (Byaruhanga, 2006; Luescher-Mamashela and Mugume, 2014; Mugume and Katusiimeh, 2016; Mutibwa, 1992).

\subsubsection{Support to student leaders during campaigns}

A cross-section of interviewed student leaders and party leaders (Interviewed, October 17, 2013, 22, $2013 \&$ \& 23, 2013) all agreed that political parties get seriously involved in the campaigns for student leadership at MAK. They further confirmed that there was a variety of material and non-material resources that were given to student leaders, mainly the party candidates for the guild presidency such as: cash; posters; training in how to campaign; nomination fees; and mentoring of student leaders by influential members of the party. The latter would in most cases be members of parliament. One of the student leaders noted that "Through the many meetings we attended in the process of strategizing, they [party leaders] usually encouraged other members to take up various positions. So in that way I can say they encouraged us, they advised us on which strategy to use, these in a way become resourceful" (Interview with guild leader C, October 24, 2013).

For a potential student leader, participating in political party activities enhances their status as candidates. Thus FDC party leader A argued in relation to the 2013 primaries ahead of the guild president elections that "some of us when we don't see [the leadership qualities] in you, we even don't go there [to MAK] to campaign, like the current guild president. If it was another student, some of us would not have gone there. Because others contestants mediocre" (Interviewed, October 22, 2013). This also highlights the considerations party leaders make before extending the needed resources to a particular student leadership candidate. It also shows the importance of aspiring student leaders participating in party activities so as to access party resources in future. 
All party leaders interviewed named almost the same resources they provide during campaigns as noted above, also confirmed by student leaders. The claim of manhandling the female FDC candidate during the 2013 guild campaigns was also highlighted by the dean of students in the interview. Thus in this case, some political parties even provided body guards for their candidate. (Interview with guild leader A, October 23, 2013). Correspondingly, a former UYD student leader (2001-2003) emphasised that party support for candidates is historical at the institution (interviewed October 22, 2013).

\subsubsection{Support to student leaders when elected into office}

Guild leader A (interviewed, October 23, 2013) explained that the party still guides her as a student leader and this mainly involves meeting those she considers to be her role models in the party. In the process she gets advice about how to deal with different issues, mainly the party leaders' opinions on how they would handle different circumstances in politics. Also activities with the party continue.

We usually have activities within the party, youth activities where the youth are in charge and whenever there are activities to be carried out at MAK, the party comes to us. These include both activities on campus but also community outreach projects whereby the party sends students as FDC members to go help out in communities (Interview with guild leader D, October 24, 2013).

Political parties also organise conferences to help groom the young leaders (Interview with guild leaders B and C, October 23, 2013 \& 24, 2013).

Having noted the opportunities political parties avail to student leaders, UPC and FDC leaders argued that, the challenge was the ruling party, i.e. the NRM, would attempt to 'poach' their student leaders.

Whenever a contesting student leader from the opposition party becomes a guild president, the NRM agents persuade them to join the NRM and this has happened three or four times already. The NRM usually attempts to take them all, it tries to bribe them. Even some of the current leaders have been given offers such as houses, vehicles and good jobs so that they join NRM (Interviews with UPC leader B, October 17, 2013).

This is also confirmed by student leaders who argue that they have been approached by the NRM to join with promises of financial rewards (Interviews with guild leaders C and D, October 24, 2013). Therefore being in power influences a party's resources ability and influence on student leaders. 


\subsubsection{Support to Student Leaders when they Graduate}

A student leader explained that when the candidate wins the elections, she/he becomes a public relations tool for the political party (Interview with guild leader B, October 23, 2013). Thus, this student leader argued that the relationship changes after election, whereby the student leader now provides more support for the political party, than that which the political party actually gives to the student leader. A party leader highlights the importance of a guild presidency win:

Winning gives motivation to party members because you know how people follow the guild elections, even after midnight you will hear the radio announcing who won the vote at MAK. Secondly we use it to groom leaders... We expect you [the student leader] to promote the party by providing good leadership and we also expect you to mobilize for the party (Interview with FDC leader A, October 22, 2013).

This confirms a relationship with high levels of resources exchange between student leaders and political parties.

\subsubsection{What the Political Party may expect from Student Leaders}

The NRM expects that when time for elections comes they use that structure (chapter) to build leaders for the guild presidency and other posts at the institution. Such student leaders will in time come to Delegates Conferences and they would be allowed to run for positions within the national network and they become national leaders. It is a nursery bed of grooming leaders (Interview with NRM leader B, October 22, 2013).

Thus, the NRM looks at student leaders as future national leaders and space is availed within the party structures for them to grow their leadership skills. But the interviewee noted that since the party was in power, the opportunities for student leaders were not only within the party but even in government. Therefore, student leaders are expected to try and keep good relations with party leaders and with party structures even in their home areas to access party-

opportunities. The relationship as discussed above, confirms the functions of recruitment and career opportunities as argued by Weinberg and Walker (1969).

\subsection{Control of Student Leaders by the Political Party}

The dean of students at MAK explained that the involvement of political parties in student politics came with many challenges for the institution. 
For instance one of the ills ... has been the commercialisation of the elections. We would want a brilliant student who is pro-students and who knows the institution and has got the university at heart to emerge the winner. Where they should look at the leadership characteristics then fellow students elect him or her. But [you can't win] if you don't have for example what here they call logistics so as to for example print posters, stage rallies, hire buses to take students from one hall to another, have the public address systems, buying gifts and so on ... (Interview with dean of students, October $23,2013)$.

The dean of students argued that this form of dependency by student leaders on political parties is a common characteristic of the relationship in Uganda. $\mathrm{He}$ further indicated that the resources availed by political parties to student leaders make it hard for independent candidates to compete. In addition he explained that this influence turned student politics into national politics whereby issues in national parliament which may have nothing or very little to do with the students consume all the leadership and political debates on campus. The dean of students further outlined that "we are also observing trends; it is lucrative to be in student leadership here" (Interview, October 23, 2013). He argued that student leadership was turning into a money-making venture for the student leaders, given the opportunities that came with it, rather than an opportunity to serve fellow students. This highlights the consequences of party politics on campus, as political parties ensure that they keep a grip on their respective student leaders.

A couple of issues emerge here. Firstly, there is a fear that the most competent students or candidates don't get to be elected due to the "commercialisation" of student politics by external forces, while political parties give the funding, expecting something in return from the student leaders. As a result student leaders' actions get controlled by off-campus forces.

However, guild leader B argued to the contrary. Indicating that after a student leader has been elected into office, even though the party may have contributed resources during the election campaign, they cannot control what he or she does on campus (Interviewed, October 23, 2013). Hence a student leader can even swap parties after entering office. Furthermore, what resonates from the analysis is that the weaker the structures within the party, the more powerful the student leaders become, such as the example of UPC. Student leaders took advantage of the weak party leadership and attempted to fill the leadership vacuum in the party. The implication of this is that the political party ends up having less control over the student leaders as they are empowered to force the party structures to do certain changes which favour their position.

It is clear from the interviews that any attempt at controlling student leaders will require some kind of "carrot and stick" method. A FDC party 
representative explained how important the resources can be to a party in this respect:

There are instances whereby the party does not have enough money and you find them [i.e., students] getting money from other sources to finance their campaigns. Now also those sources want something in return so as to access the privileges that come with having a guild president, such as a status for the party. ...Like in any country, if you do not finance the candidate you know there are those times when that candidate feels after all ... what was the role of my party in my reaching here? (Interview with FDC leader A, October 22, 2013).

The dean of students noted that as much as political parties may try to control student leaders, the whole electoral process offers student leaders a learning experience. Furthermore, the dean explained:

We teach them things trying to re-orient [them but] some of them know it by the way that [using political parties] is only a route through which they can reach leadership. Some of them understand it very well. In fact we have had cases of students who have changed parties just towards elections or after (Interview with dean of students, October 23, 2013).

This highlights how student leaders use political parties for their political success while at the same time trying to run away from being controlled. Another FDC leader indicated that student leaders manipulate political parties, mostly those parties with a popular brand, during campaigns, but after winning they cut ties:

I think we are now a brand as a party that talks about a better future and those who are looking at Uganda that does not stop today they want to join us. Those who think about what we call the common good and fairness want to join us but of course there are those who want to join us because we have the crowd. Those you can never rule out, like I said those after winning they are not with you. Even after leaving campus you never see them talk politics again (Interview with FDC leader A, October 22, 2013).

Therefore students at times cut ties with political parties after elections to avoid the responsibilities (and potential control) that come with having used party resources during campaigns. The approach of the NRM is illustrated here by another party leader towards recruiting. For example, if the president makes a policy decision which the student leaders may disagree with and they protest mostly at MAK.

Those student leaders will be summoned to the State House to explain to him what their demands are. Afterwards he asks the others on the delegation to leave [the room]; he wants to talk to you [the guild president]. If the 
person is not of strong character they break. [A former guild president explained his encounter with the president] that the president said to him, you see now we are talking as presidents ... praising you, ... he [the student leader] would say but I'm not like you, but the president would keep insisting that we are meeting like presidents not like any one... I was also voted into office like you now let's talk as presidents. So defending that becomes a challenge (Interviewed FDC leader A, October 22, 2013).

The argument here is that most student leaders 'break' and a deal is struck there and then for the student leader to join the ruling party with specific promises made to the guild president. This shows the power and influence that comes with a particular political party being in office.

\subsection{Reflecting on the Schmitter and Streeck Theoretical Framework}

The Schmitter and Streeck (1999) framework adapted for this study focuses on student leaders and political parties by design (i.e. student leaders' participation in the political party and representation through the political party) and in the process less consideration is directed at those whom student leaders are meant to represent (students). It bases itself on the assumption that student leaders as representatives represent student interests almost by default. In addition the theoretical framework as noted in Figure 4 focuses on autonomy (more or less autonomy) of the student leaders, which is conceptualised as their level of independence in relation to the decisions they make. However applying the framework to the case above shows a more nuanced interaction, with no single actor having full autonomy. Political parties derive their authority in the relationship independently from the many different and powerful constituencies that make up a political party, while student leaders make up a small constituency in a party. Therefore the application of the adapted theoretical framework to the case shows that there is a constant attempt by the student leaders and the political parties to gain influence by one over the other. However, given that the relationship does not play out on a level playing field, political parties always have more power over student leaders than vice versa and are therefore able to influence what student leaders do.

Power is influenced by resources and incentives in two ways: Firstly, the more incentives a political party avails to student leaders in answering their demands/interests, the more power and thus control it will have over them [other factors considered constant]. Secondly, the more resources a political party will be able to access, the more incentives it will be able to give to student leaders and thus able to control them, which results in empowerment for the student leaders. In relation to this point, the distinction between ruling party and opposition party is important (Byaruhanga, 2006). However in relation to the 
associative actions of the framework namely; Participation of student leaders in the political party, Representation of student leaders, Goods and services exchange, and Control over student leaders, their characteristics or the way they are defined and thus used in the analysis remains the same. Therefore the indicators proposed during the process of adapting the framework to the MAK case study remain important while analysing how student leaders and party leaders relate.

\section{Conclusion}

The study confirms the continued historical relationship between student leaders and political parties in Uganda, which Byaruhanga (2006) reports in his study, and suggests that this relationship is even stronger now with more new political parties in the country in competition with each other. Furthermore, student leaders from Makerere University are still the most likely to end up as powerful politicians in the country or powerful bureaucrats, even while many new universities in Uganda have been established especially since the 1990s. This historical relationship continues to serve the function of renewing the political and bureaucratic elite in the country generally in terms of the historical recruitment function of student political affiliation with political parties as argued by Weinberg and Walker (1969). The relationship with political parties is also clearly important to any guild presidential candidate. Political parties provide the goods and services necessary for a party flag-bearer to wage a successful election campaign. Overall, goods and services provided by a party differ between those availed during campaigns and after winning an election. The expectations of student leaders regarding a possible political career after graduating, and conversely the expectations of the political party in that whole process, tend to shift over the process of association and greatly impact on the levels of influence (or even control) that a political party may exert over a student leader.

The paper shows that while student leaders may influence some of the weak political parties (in terms of party policies), student leaders are a weak constituency within any political party. As a result, student leaders may influence decisions mostly in the structures of a weak political party but still the final decisions even in a weak party are made by the main political party leadership and not student leaders. In terms of its effects on student representation in particular, the study shows that the relationship certainly harbours its ambiguities. It benefits student leaders and political parties directly; in the process, however, the actual representation of student interests may become a minor issue. We have pointed out, however, that the framework adapted from Schmitter and Streek, fails to consider in detail the way student interests and concerns are expressed, and intermediated authentically by student 
leaders into institutional decision-making. Rather it is an assumption that student leaders' interests are congruent with those of the general student body of Makerere University. Overall, given the complex and at times contradictory relationship shown in this study, a level of institutional intervention to safeguard student interest representation in the long run may be required.

\section{References}

Altbach, P.G. (1968). Student Revolt in Europe. Economic and Political Weekly, 3(19), 755-756.

Altbach, P.G. (1984). Student Politics in the Third World. Higher Education, 13(6), 635-655.

Altbach, P.G. (1989). Perspectives on Student Activism. Comparative Education, 25(1), 97-110.

Babbie, E. and Mouton, J. (2001). The Practice of Social Research. Oxford: Oxford University Press.

Byaruhanga, F. K. (2006). Student power in Africa's Higher Education: A case of Makerere University. New York: Routledge.

Gyampo, R.E.V. (2013). Student activism and democratic quality in Ghana's fourth Republic. Journal of student affairs in Africa, 1 (1\&2), 49-66, DOI: 10.14426/jsaa.v1i1-2.24.

Jungblut, J. and Weber, R. (2012). National student governance in Germany: The case of FZS. European Journal of Higher Education, 2(1), 47-62.

Klemenčič, M. (2012). Student representation in Western Europe: Introduction to the special issue. European Journal of Higher Education, 2(1), pp. 2-19.

Lipset, S.M. (1966). Approaches to the Study of Student Political Behaviour: University Students and Politics in Underdeveloped Countries. Comparative Education Review. pp. 132-162. Minerva, 3(1), 15-56. (Autumn of 1964 \& Reprinted in 1966).

Luescher, T.M. (2009). Student governance in transition: University democratisation and managerialism-A governance approach to the study of student politics and the case of the University of Cape Town. Unpublished doctoral thesis, University of Cape Town.

Luescher-Mamashela, T.M. (2010). 'From University Democratisation to Managerialism: The changing legitimation of university governance and the place of students', Tertiary Education and Management, 16(40), 259-283. DOI: 10.1080/13583883.2010.529161

Luescher-Mamashela, T.M. (2013) Student representation in university decision making: good reasons, a new lens? Studies in Higher Education, 38(10), 1442-1456, DOI:10.1080/03075079.2011.625496. 